Chenopodium album ( بر رسى رفتار جوانهزنى و خواب بذر در علفهاى هرز سلمهتره

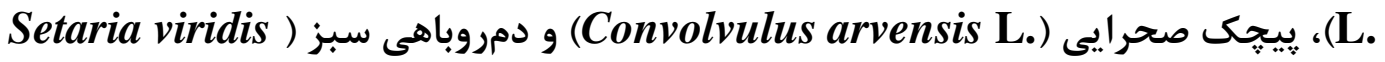

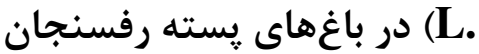

مصطفى على نقىز اده "،"، محمد خواجه حسينى صالح آباد ‘ ، سيد احمد حسينى "، محمدحسن راشد محصل "

$$
\begin{aligned}
& \text { ' استاديار گروه كشاورزى، دانشعاه ييام نور }
\end{aligned}
$$

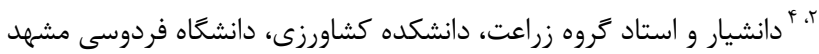

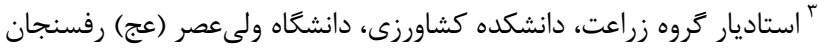

$$
\begin{aligned}
& \text { alinaghizadeh@pnu.ac.ir : }
\end{aligned}
$$

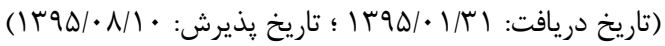

بهمنظور بررسى رفتار جوانهزنى و روشهاى شكستن خواب بذر تودههاى مختلف علفهاى هرز

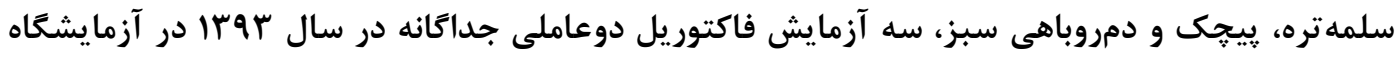

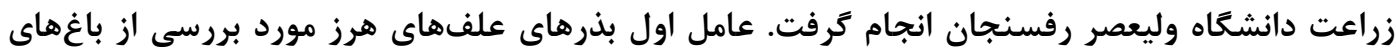

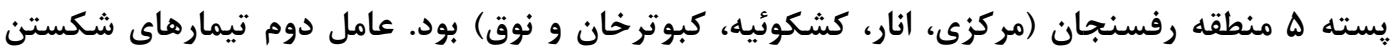

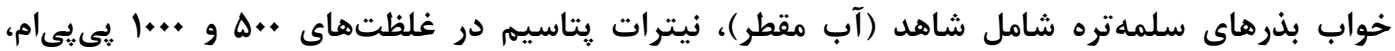
خراشدهى با اسيد سولفوريك غليظ در زمانهاى ه و •ا دقيقه و سرمادهى مرطوب در زمانهاى ا، ب و هـ هفته، تيمارهاى شكستن خواب بذرهاى ريجنى شامل شاهد، خراشدهى با سمباده، خراشدهى با اسيد

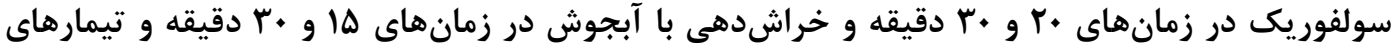

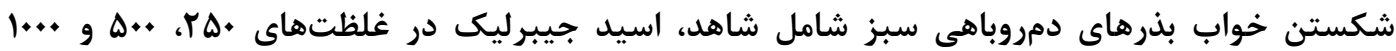

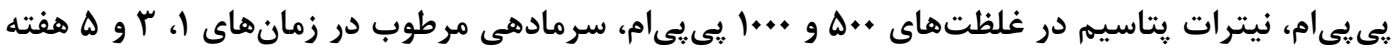

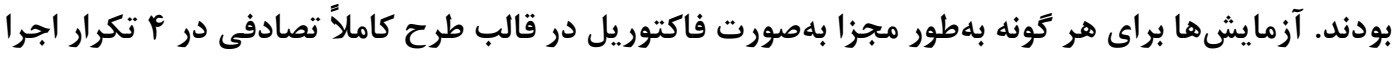

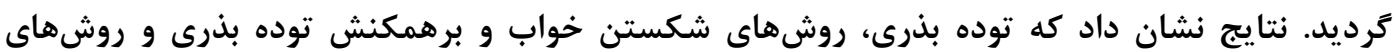
شكستن خواب اثر معنىدارى بر درصد جوانهزنى و متوسط زمان جوانهزنى بذرهاى علف هرز هر سه كونه داشت بهطورى كه تيمار ه هفته سرمادهى مرطوب در بذرهاى سلمه تره توده نوق با ميانگين جوانهزنى

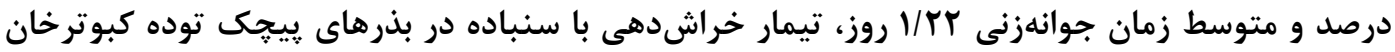

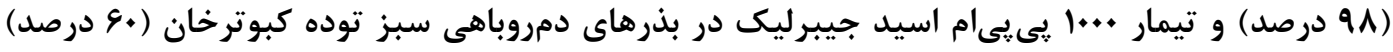

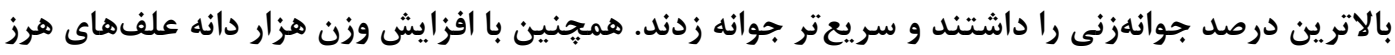
مورد بر رسى، درصد جوانهزنى نيز افزايش يافت.

وازههاى كليدى: اسيد جيبرليك ، خراشدهى، خواب بذر، سرمادهى مرطوب، نيترات پِاسيم 
بذرها وجود دارد (لطيفى، •^^ץ|). انجمن بينالمللى

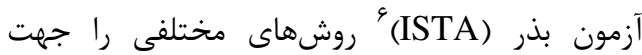

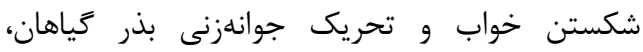

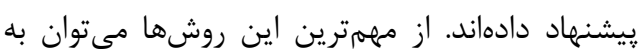
استراتيفيكاسيون، خراشدهى (مكانيكى و شيميايى)، استفاده از محلول هاى مختلف تحريك كننده جوانهزنى إنى (جيبرلين، نيترات رتاسيه، اسيد نيتريك، وِلىاتيلن

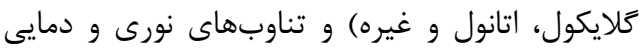

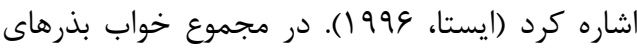

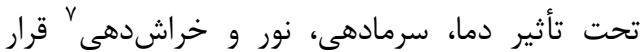

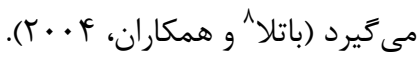

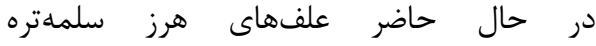
بيجیى (Chenopodium album L.) و دمروباهى سبز (Convolvulus arvensis L.) در اكثر باغهاى پپته (Setaria viridis L.) شهرستان رفسنجان حضور و تراكم بالايى داشته كه علاوه بر كاهش محصول، در عمليات داشت و برداشت محصول نيز اختلال ايجاد مى كنند. سلمهتره علف

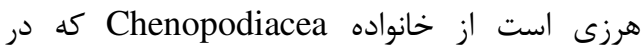
باغهاى، زمينهاى باير و حاشيه جادها كَترش

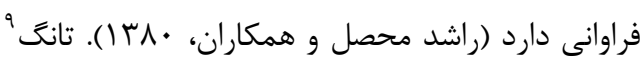

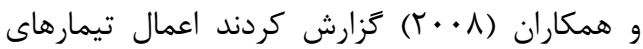
ييشسرمادهى و تركيبات نيتروزندار نسبت به ساير تيمارهاى شكستن خواب، تأثير بالاترى بر درصد

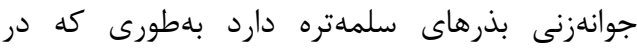

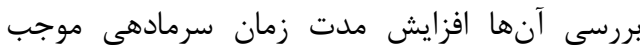

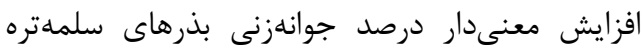

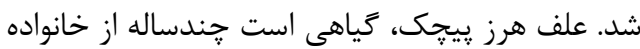
Convolvulaceae زيرزمينى تكثير مىيابد. بذرهاى يِيجك به دليل آنكه

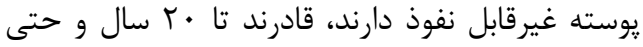

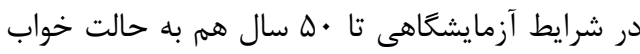
باقىمانده و قوّه ناميّه خود را از دست ندهند (راشد

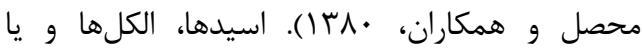

\footnotetext{
${ }^{6}$ International Seed Testing Association ${ }^{7}$ Scarification

${ }^{8}$ Batlla

${ }^{9}$ Tang
}

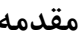
از جمله عوامل مهمم و فراموششده در مديريت باغهاى پسته، علفهاى هرز مىباشد. اين علفهاى إن هرز، كياهانى هستند كه با استفاده از آب و مواد باد آناد غذايى خاك باعث فقر غذايى و ايجاد تنش خشكى در باغهاى يسته مىشوند. با توجه به اينكه باغهاى يسته

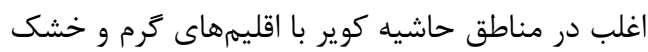
احداث شدهاند، اهميت رقابت علفهاى هرز در مصرف آب آبيارى بهخوبى مشخص است. بهعلاوه علفهاى نداى

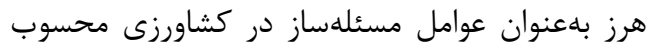
مىشوند، زيرا بر كيفيت و عملكرد محصول تأثير سوء

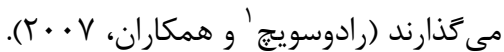
يكى از مهمترين مكانيسمهاى حفظ بقاء دران

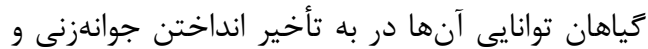

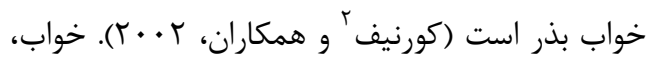
استراحت يا وقفه موقت در رشد كياه بوده كه در اين وضعيت با وجود مناسب بودن شرايط براى جوانهزنى، بذر براى مدت نامعلومى در حالت استراحت باقى باتى

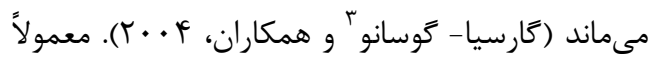
بذر كونههاى وحشى خواب شديدترى ران نشان

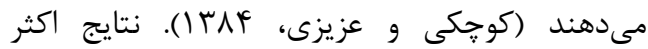
تحقيقات مؤيد آن است كه بذر علفهاى هرز، كياهان دارويى و ساير كونههاى وحشى به دليل ساز كارى إنى بومشناختى داراى سازوكارهاى مختلف خواب از جمله يوسته سخت، فيزيولوزيكى و القايى مى باشند (كويلند

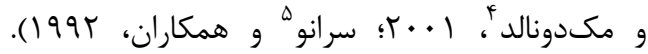

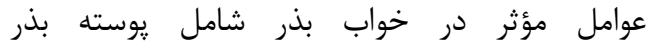
(نفوذنايذيرى يوسته بذر نسبت به آب، نفوذنإيذيرى يوسته بذر نسبت به اكسيرن و مقاومت مكانيكى يوسته بذر)، جنين (جنين در حال خواب و جنين نابالغ) و بازدارندهها (وجود مواد بازدارنده در بذرهان إنابن مىباشد كه هر كدام از اين سازوكارها به دائايل كوناكونى اتفاق افتاده و با توجه به عامل ايجادكننده خواب، روشهاى مختلفى براى تحريك جوانهزنى

\footnotetext{
${ }^{1}$ Radosevich

${ }^{2}$ Koornneef

${ }^{3}$ Garcia-Gusano

${ }^{4}$ Copeland and Mcdonald

${ }^{5}$ Serano
} 
مجله يزوهشهاى بذر ايران/ سال سوم/ شماره دوم/ هو؟1

جدول ا- مشخصات جغرافيايى و اقليمى باغهاى يسته مورد مطالعه

\begin{tabular}{|c|c|c|c|c|c|c|c|}
\hline اقليم & سطح دريا & متوسط & (سلسيوس) سانلانه & عرض جغرافيايى & طول جغرافيايى & (كيلومترمربع) & 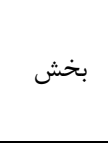 \\
\hline خرم و خيلى & $14 \cdot \Lambda$ & $\Lambda \Lambda$ & $I V / \Lambda$ & , & \langle|$I^{\circ} \Delta \Delta^{\prime}-\Delta V^{\circ} \Delta F$ & $\mid f \cdot \Lambda$ & 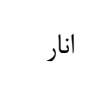 \\
\hline ترم و خشك & ITr. & $\Lambda 9 / 4$ & $\mathrm{IV} / \mathrm{V}$ & . & $\cdot r^{\circ} \Delta \varphi^{\prime}-1 \varphi^{\circ} \Delta \Delta$ & ITr. & نوق \\
\hline كرم و خشك & IDTK & $91 / 9$ & $\mid V / 9$ & 'Fr r.'- $10^{\circ} r$. & ${ }^{\prime} \Delta r^{\circ} \Delta \Delta^{\prime}-1 \Lambda^{\circ} \Delta \Delta$ & IDTr & كشكوئيه \\
\hline ترم و خشك & 1911 & $1 \cdot 4$ & $I V / F$ & 'rg r.'- $11^{\circ} r$. & ${ }^{\prime} \mu F^{\circ} \Delta \varphi^{\prime}-\Delta \varphi^{\circ} Y F$ & 1911 & كبوترخان \\
\hline ترم و خشك & $109 \Lambda$ & $1 \cdot 1$ & $I V / 9$ & ' $\mid V^{\circ} r I^{\prime}-r q^{\circ} \Delta \Delta$ & ${ }^{\prime} F{ }^{\circ} \Delta \varphi^{\prime}-\Delta \varphi^{\circ} \Delta F$ & $\mid \Delta S \Lambda$ & مركزى \\
\hline
\end{tabular}

مىباشد كه در حوضه آبخيز لوت و در جنوب شرقى كوير مركزى ايران قرار دارد. بذرهاى علفهاى هرز

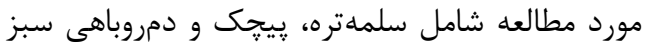

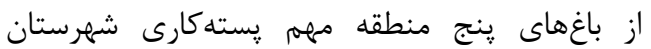
رفسنجان شامل مناطق مركزى، انار، كشكوئيه، كبوترخان و نوق (با توجه به خسارتزا بودن و حضور هر گونه در منطقه) جمع آورى شدند (جدول لون (1).

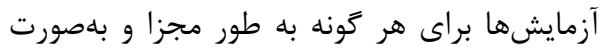
فاكتوريل در قالب طرح كاملاً تصادفى در بَ ت تكرار

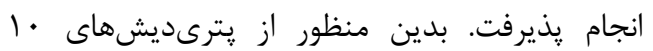

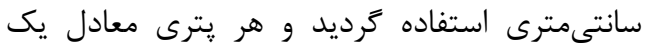
تكرار در نظر گرفته شد. در هر يترى از يك كاغذ صافى واتمن شماره يك باعنوان بستر جوانهزنى بذر درى

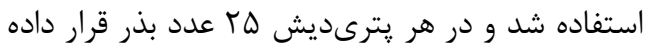

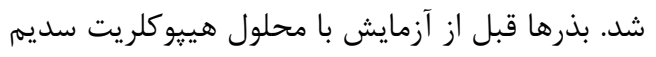

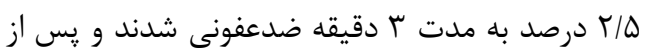
شستشو با آب مقطر، تيمارهاى موردنظر اعمال گرديد.

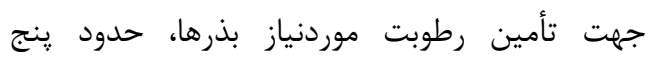

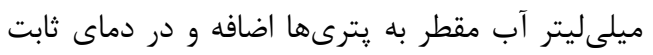

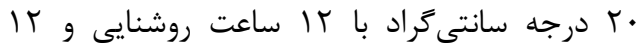
ساعت تاريكى، درون دستخاه انكوباتور قرار گرفتند. جهت جلوگيرى از تبخير و كاهش رطوبت، دور دور داعنى يترىها بالوسيله يارافيلم مسدود گرديد. در طول مدت

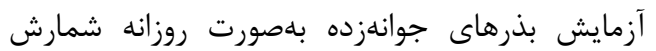

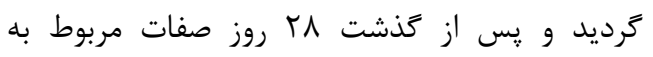
جوانهزنى و رشد كياهجه محاسبه شد. ملاكى جوانهزنى

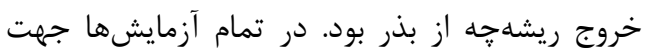

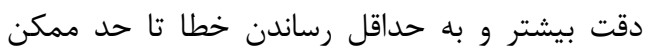

خراشهاى مكانيكى از تيمارهاى مؤثر بر شكستكى اين دوره محسوب مىشوند (راشد محصل و همكاران،

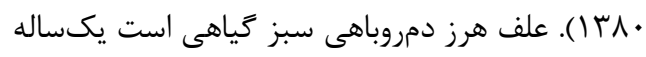
از خانواده Poaceae كه توسط بذر تكثير مىيابد.

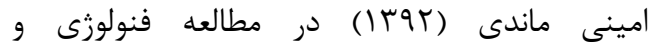
اكوفيزيولوزى بذر سه گونه دمروباهى گزارش كرد كه

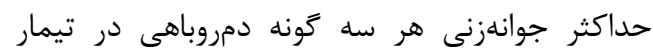
• ييش تيمار بذرهاى با جيبرليك اسيد نسبت به

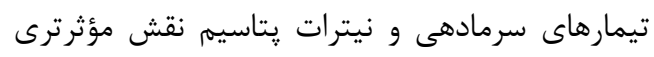
در افزايش درصد سبز شدن بذرهاى هر سه كونه داشت. دانستن زمان جوانهزنى و خواب بذر، كاربرد عملى درخور توجهى در مديريت علفهاى هرز دارد

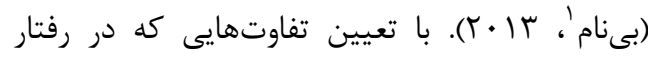

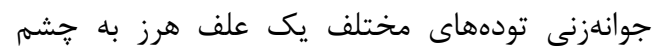
مىخورد، مىتوان علت نياز به روشهاى متهاى متفاوت

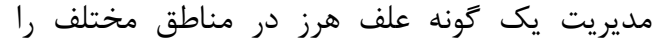

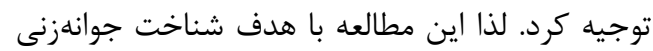

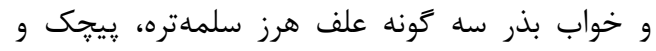
دمروباهى سبز در باغهاى ينج منطقه يستهخيز شهرستان رفسنجان طراحى و اجرا شد.

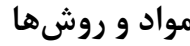

اين تحقيق در سال سوسا در آزمايشگاه زراعت دانشكده كشاورزى دانشگاه وليعصر رفسنجان اجرا شد. حوضه رفسنجان بخش نسبتاً وسيعى از استان كرمان

\footnotetext{
${ }^{1}$ Anonymous
} 


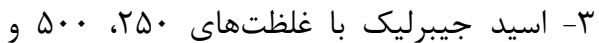

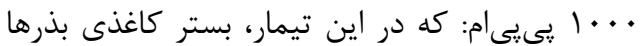

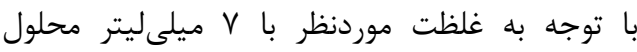
جيبرليك اسيد مرطوب گرديد.

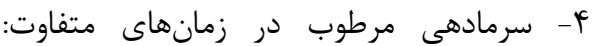
بذرهاى مرطوب شده علف هرز دمروباهى سبز داخل

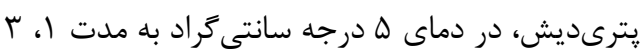
و ه هفته در يخجال قرار زرفتند.

براى محاسبه درصد جوانهزنى از رابطه (1) و براى محاسبه متوسط زمان جوانهزنى از رابطه (r) استفاده دراه

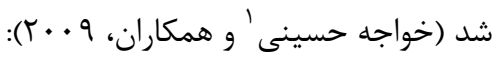
رابطه 1:

$$
G P=\sum\left(\frac{n}{N}\right) \times 100
$$

$$
M G T=\sum\left(n_{i} \times t_{i}\right) / N
$$

رابطه r: n : تعداد بذرهاى جوانهزده جديد.

$$
\text { N ت تعداد كل بذرها. N }
$$

: تعداد بذرهاى جوانهزده در يك فاصله زمانى :

مشخص.

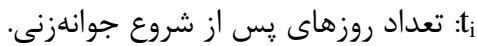

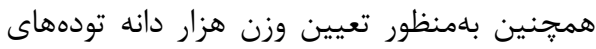

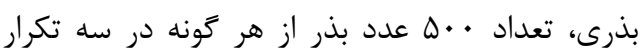
بلهوسيله ترازوى دقيق (با دقت يكهزارم گرم) شمارش درد و توزين شد.

تجزيه و تحليل آمارى با استفاده از نرمافزار SAS

نxcel نسخه 9.1 و رسم نمودارها توسط نرمافزار صورت گرفت. ابتدا شرط نرمال بودن دادهها با آزمون

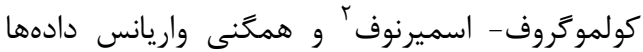

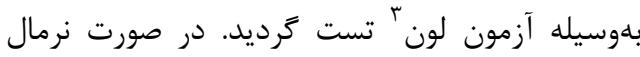
نبودن دادهها از تبديل دادهها استفاده شد. مقايسه

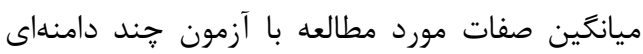
دانكن در سطح احتمال ه درصد صورت يذيرفت.

\footnotetext{
${ }^{1}$ Khijeh-Hoseini

${ }^{2}$ Kolmogorov-Smirnov

${ }^{3}$ Levene
}

بذرهايى انتخاب شدند كه از نظر اندازه و قدرت رشد، يكنواخت به نظر مىرسيدند. آزمايشهاى اوليه نشان داد كه بذرهاى هر سه گونه داراى خواب بوده و در

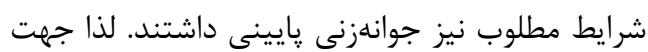
رفع خواب بذرهاى، طبق قوانين انجمن بينالمللى آزمون بذر ISTA و با توجه به نوع گَونهها، تيمارهاى ذيل اعمال شد (ايستا، 1999 (1). در آزمايش اول جهت شكستن خواب بذرهاى علف الف الفال هرز سلمهتره، 1 تيمار شامل: 1- آشاهد (آب مقطر).

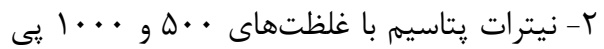
يى ام: كه در اين تيمار، بستر كاغذى بذرها با توجه به

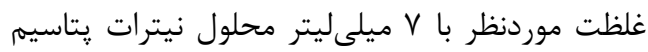

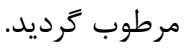

r- خراشدهى شيميايى يوسته بذر باد اسيد سولفوريك غليظ در زمانهاى متفاوت هـ هو • ا دقيقه.

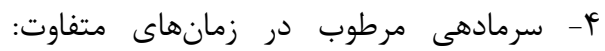
بذرهاى مرطوب شده علف هرز سلمهتره داخل يترىديش، در دماى ه درجه سانتى و ه هفته در يخجال قرار گرفتند. در آزمايش دوم جهت شكستن خواب بذرهاى علف هرز پيجنك، 9 تيمار شامل:

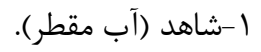

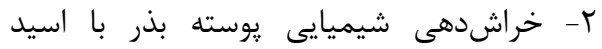

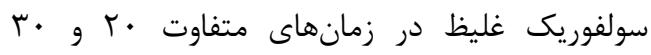
دقيقه. ץ- خراشدهى فيزيكى : خوسته بذر با سمباده كاغذى.

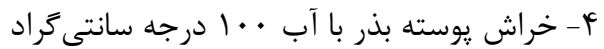

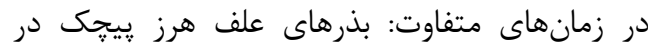
زمانهاى • ا و ها دقيقه در آبجوش خيسانده شد. و در آزمايش سوم جهت شكستن خواب بذرهاى علف هرز دمروباهى سبز، 9 تيمار شامل:

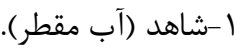

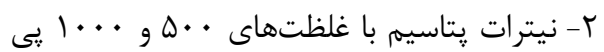

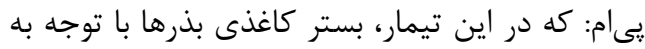

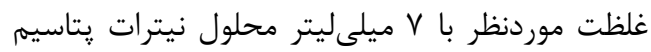

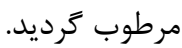


در تمامى تودهها بلهز توده مركزى، تيمارهاى

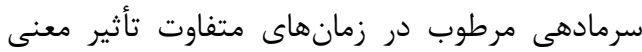
دارى بر شكستن خواب بذرهاى علف هرز سلمهتره

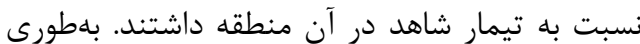
كه در كليه تودهها با افزايش مدت زمان سرمادهى مرطوب از 1 هفته به ه هفته، درصد جوانهزنى بهطور

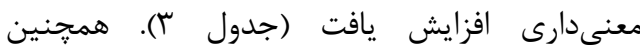
تيمارهاى سرمادهى مرطوب در زمانهاى متفاوت، يايينترين متوسط زمان جوانهزنى را در تمامى تودهها

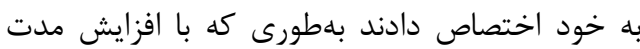
زمان سرمادهى مرطوب از 1 هفته به ه هفته، متوسط زمان جوانهزنى نيز كاهش يافت و بذرهاى سريعتر

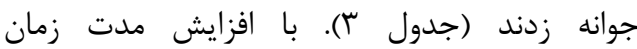

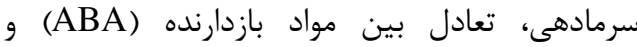
تحريك كننده (اسيد جيبرليك) به سمت وجود مواد به به به تحريككننده بيشتر، ريش ميشرود؛ بنابراين دماهاى يايين از طريق تحريك توليد هورمون جيبرلين و كاهش ميزان اسيد آبسيزيك، سبب توازن بين اين هورمونها مىشود و به دنبال آن از طريق القاء سنتز

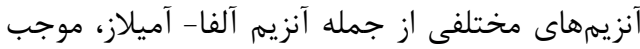
شكستن ذخاير غذايى بذر زرديده و آنها را به مواد قابلاستفاده جنين تبديل مى كند و در نهايت باعث

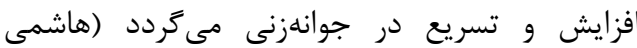

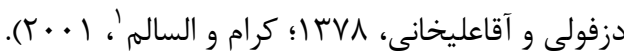
به نظر مىرسد تفاوت در مدت زمان سرمادهى مرطوب براى شكستن خواب، مربوط به شرايط

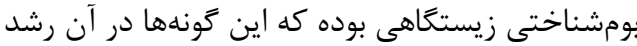
مى كنند كه باعث ايجاد درجات مختلفى از خواب در بر برد

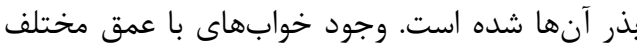
باعث توزيع جوانهزنى در طول زمان مىشود كه اين

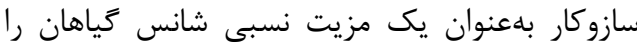

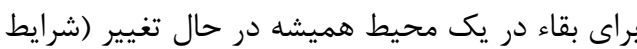
نامساعد) افزايش مى دهد (شريفى و همكاران، Fqج ().
نتايج و بحث علف هرز سلمه تره نتايج حاصل از تجزيه واريانس نشان داد توده بذرى، تيمارهاى شكستن خواب و برهمكنش توده

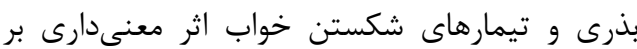
درصد جوانهزنى و متوسط زمان جوانهزنى علف هرز سلمهتره در سطح يك درصد داشتند (جدول r). نتايج نشان داد كه تمامى تيمارهاى اعمالشده دهره جهت شكستن خواب بذرهاى علف هرز سلمهتره، مؤثر واقع گرديده است با اين توضيح كه در تودههاى مختلف تيمارهاى شكستن خواب بذرهاى، متفاوت عمل كردهاند (جدول ب). تيمار ه هفته سرمادهى مرطوب در توده بذرى نوق با ميانخين 9V درصد، بالاترين درصد جوانهزنى و يايينترين متوسط زمان جوانهزنى (r/T/ روز) را داشت كه از نظر درصد جوانهزنى اختلاف معنى دارى بإ كاربرد اسيد سولفوريك به مدت • ا دقيقه نداشتند. در مقابل تيمار ا هفته سرمادهى مرطوب در توده مركزى با ميانگين VV (آب مقطر) در توده مركزى، بالاترين متوسط زمان

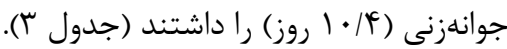
مكانيسم واقعى رفع خواب در اثر سرما هنوز

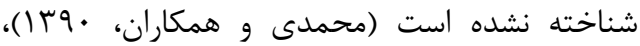
بعضى از دانشمندان تغيير شكلهايى را كه در ساختار

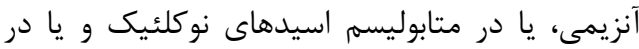

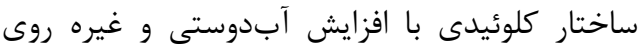

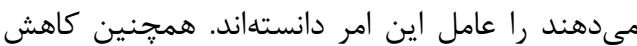
يا حذف بازدارندههاى جوانهزنى درون بذر مثلاً كاهش ردي

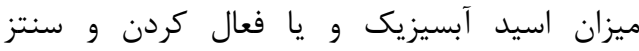
جيبرلين را نيز از جمله تأثيرهاى سرما دانستهان آنداند (هاشمى دزفولى و آقاعليخانى، YVA

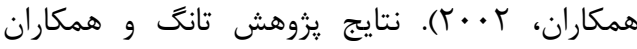

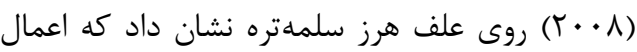
تيمار ها لا روز سرمادهى و نور نسبت به ساير تيمارهاى شكستن خواب، بالاترين درصد جوانهزنى را داشتند بهطورى كه در بررسى آنها افزايش مدت زمان زمان سرمادهى موجب افزايش درصد جوانهزنى شد.

\footnotetext{
${ }^{1}$ Karam and Al-salem
} 
نقىزاده و همكاران: بررسى رفتار جوانهزنى و خواب بذر در علفهاى هرز...

\begin{tabular}{|c|c|c|c|}
\hline \multicolumn{4}{|c|}{ هرز سلمهتره r - تجزيه واريانس تأثير توده بذرى و تيمارهاى شكستن خواب بذر بر درصد و متوسط زمان جوانهزنى علف } \\
\hline \multicolumn{2}{|c|}{ ميانگين مربعات } & \multirow{2}{*}{ درجه آزادى } & \multirow{2}{*}{ 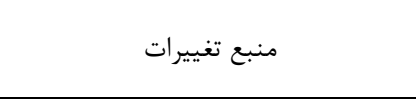 } \\
\hline متوسط زمان جوانهزنى & درصد جوانهزنى & & \\
\hline$r \Delta / \mu^{* *}$ & GGGY/KR & $r$ & توده بذرى \\
\hline $4 \cdot 10 V^{* *}$ & $F \vee \Delta \cdot / \Lambda \Delta^{* *}$ & V & تيمارهاى شكستن خواب \\
\hline $\boldsymbol{F} / \cdot^{* *}$ & $|F| F / \cdot F^{* * *}$ & rI & توده بذرى × تيمارهاى شكستن خواب \\
\hline$\cdot / \pi F$ & $\varphi \& / 0 \Lambda$ & 99 & خطا \\
\hline$|r / 9|$ & $11 / 49$ & & ضريب تغييرات (درصد) \\
\hline
\end{tabular}

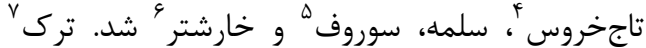

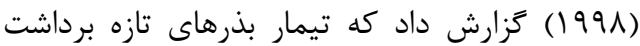

شده گَونه علفشور (Atriplex nummularia) با بارس

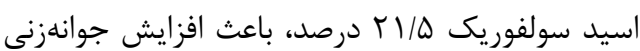
اين بذرهاى نسبت به شاهد گرديد.

در بررسى حاضر در كليه تودهها، اعمال تيمار

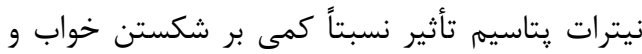
جوانهزنى بذرهاى علف هرز سلمهتره نسبت به تيمار شاهد در هر توده داشت باططورى كه در تمام تودههاى بـى بهري

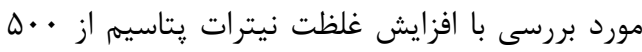

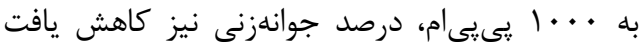

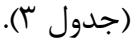

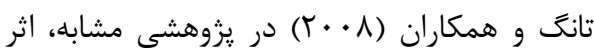

تركيبات نيتروزن دار از جمله NH $\mathrm{NH}_{4} \mathrm{Cl}$ سلمهتره بررسى نمودند و ززارش كردند اين تركيبات بلهور مؤثرى باعث شكستن خواب و و جوانهزنى بذرهاى علف هرز سلمهتره شد. اگرخه مكانيسمهايى كه از طريق آنها نيترات، جوانهزنى را تحريك مى كند سند بهخوبى شناخته نشده است، اما اثر اين يون بر روى روى ناقلين غشاهاى سلولى يك فرض محتمل مىباشد (كارسن و هيل هورست ؛ بو (199).

\footnotetext{
${ }^{4}$ Amaranthus retroflexus

${ }^{5}$ Echinochloa crus-galli

${ }^{6}$ Alhagi maurorum

${ }^{7}$ Thurk

${ }^{8}$ Karssen and Hillhourst
}

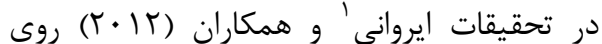
گياه Dorema ammoniacuma

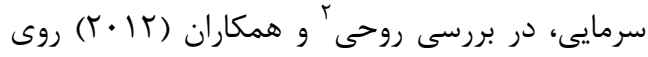

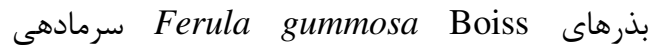
مرطوب V هفتهاى و در مطالعه وانديلوك 'ّ و همكاران

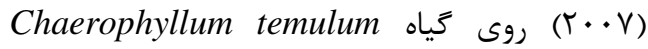
سرمادهى مرطوب را هفتهاى را بهترين زمان براى شكستن خواب بذرهاى معرفى شدند. نصيرى و همكاران (سNץ|) بهترين تيمار براى

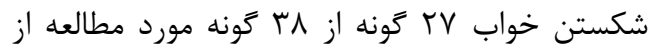
جمله گFونههاى كما (Ferula ovina)، باريجه (Ferula gomusa) را سرمادهى دانستند. در اين يزوهش اعمال تيمار خراشدهى شيميايى

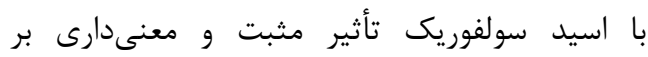
شكستن خواب و جوانهزنى بذرهاى علف هرز سلمهتره داشت بهطورى كه در تمامى تودهها با افزايش مدت زمان تيمار با اسيد از له دقيقه به ·ـ دمقيقه، درصد جوانهزنى بذرهاى افزايش يافت. تحقيقات انجامگرفته

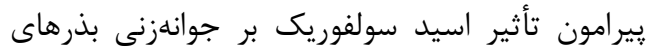

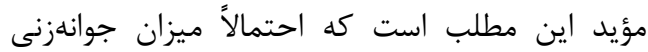
بذرها بستخى به غلظت اسيد و مدت زمان مان تماس بذر

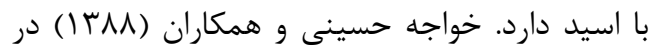
بررسى خواب بذر بيست گَونه علف هرز گزارش دادند كه تيمار اسيد سولفوريك باعث جوانهزنى بذرهاى

\footnotetext{
${ }^{1}$ Irvani

${ }^{2}$ Rouhi

${ }^{3}$ Vandelook
} 


\begin{tabular}{|c|c|c|c|}
\hline \multirow{2}{*}{ متوسط زمان جوانهزنى (روز) } & \multirow{2}{*}{ درصد جوانهزنى } & \multicolumn{2}{|l|}{ تيمارها } \\
\hline & & تيمارهاى شكستن خواب بذر & توده بذرى \\
\hline$\Delta / \Delta r e-g$ & vie-h & نيترات يتاسيم ppm 500 & \multirow{8}{*}{ انار } \\
\hline$\Lambda / \cdot \Delta b$ & S।hij & pيترات يتاسيم ppm 1000 & \\
\hline F/VIghi & $\vee \varsigma d-g$ & اسيد سولفوريك ه دقيقه & \\
\hline$r / \Lambda r i j$ & $9 r a b$ & اسيد سولفوريك • ا دقيقه & \\
\hline$r / r v i k l$ & $99 f-i$ & سرمادهى مرطوب يك هفته & \\
\hline r/v^klm & vяd-g & سرمادهى مرطوب سه هفته & \\
\hline $1 / 94 \mathrm{mn}$ & $\wedge \Delta \mathrm{bcd}$ & سرمادهى مرطوب ينج هفته & \\
\hline$\Delta / r r e-g$ & 99ghi & شاهد (آب مقطر) & \\
\hline $\mathrm{r} / \Lambda \cdot \mathrm{ij}$ & $\mathrm{f} \Delta \mathrm{kl}$ & 500 ppm نيترات پِتاسيمم & \multirow{8}{*}{ كشكوئيه } \\
\hline$f / \wedge \Delta f g h$ & rrop & 1000 ppm نيترات يتاسيم & \\
\hline ఎ/99def & q.hij & اسيد سولفوريك ه دقيقه & \\
\hline$\Delta / \cdot \Delta$ efg & $\wedge \mathrm{Vabc}$ & اسيد سولفوريك · ا دقيقه & \\
\hline r/\ধjkl & १øop & سرمادهى مرطوب يك هفته & \\
\hline r/vAklm & $\varphi \varphi \mathrm{k}$ & سرمادهى مرطوب سه هفته & \\
\hline$r / \omega \cdot \operatorname{lm}$ & ६. hij & سرمادهى مرطوب ينج هفته & \\
\hline$\Lambda / r \wedge b$ & ronop & شاهد (آب مقطر) & \\
\hline$\Delta / l / d-g$ & Qqij & 500 ppm نيترات پِتاسيم & \multirow{8}{*}{ 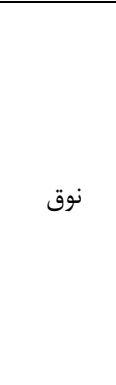 } \\
\hline $9 / 99 \mathrm{c}$ & frlmn & 1000 ppm نيترات يتاسيم & \\
\hline$r / \Delta r j k$ & ४৭c-f & اسيد سولفوريك ه دقيقه & \\
\hline$r / \cdot 9 j \mathrm{kl}$ & $\wedge 9 a b c$ & اسيد سولفوريك · ا دقيقه & \\
\hline $1 / 91 \mathrm{n}$ & \&Vghi & سرمادهى مرطوب يك هفته & \\
\hline $1 / 4 r n$ & qهhi & سرمادهى مرطوب سه هفته & \\
\hline $1 / r r n$ & $9 \vee a$ & سرمادهى مرطوب ينج هفته & \\
\hline $91 \cdot 9 \mathrm{~d}$ & $\Delta । j k$ & شاهد (آب مقطر) & \\
\hline Q/9rde & $\uparrow \wedge \mathrm{k}$ & 500 ppm نيترات يتاسيم & \multirow{8}{*}{ 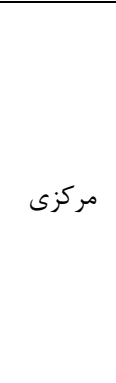 } \\
\hline$v / q \cdot b$ & rolmn & 1000 ppm نيترات يتاسيم & \\
\hline$V / A r b$ & NIcde & اسيد سولفوريك ه دقيقه & \\
\hline$\Delta / \mathrm{rrdef}$ & $\wedge \notin \mathrm{bcd}$ & اسيد سولفوريك · ا دقيقه & \\
\hline $\mathrm{f} / \cdot \Delta$ hij & rvn & سرمادهى مرطوب يك هفته & \\
\hline$r / \wedge r i j$ & rymn & سرمادهى مرطوب سه هفته & \\
\hline$\Gamma / F \backslash j \mathrm{kl}$ & $\uparrow \wedge \mathrm{k}$ & سرمادهى مرطوب ينج هفته & \\
\hline $1 \cdot / 4 r a$ & rumn & شاهد (آب مقطر) & \\
\hline
\end{tabular}

$$
\begin{aligned}
& \text { البته عقيده بر آن است كه اين مواد، احتمالاً با يك فرايند، نيازمند اكسيزن تلقى شده است كه براى }
\end{aligned}
$$

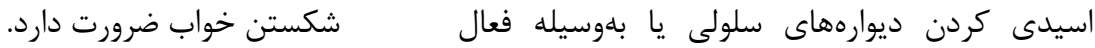

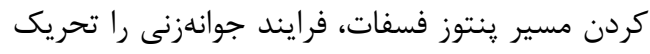

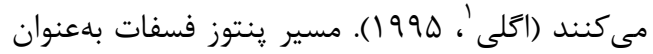

${ }^{1}$ Egely 
نقىزاده و همكاران: بررسى رفتار جوانهزنى و خواب بذر در علفهاى هرز...

\begin{tabular}{|c|c|c|c|c|}
\hline \multicolumn{5}{|c|}{ حدول F- تجزيه واريانس مربوط به وزن هزار دانه در تودههاى بذرى متفاوت سلمهتره، يِيجى و دمروباهى سبز } \\
\hline \multicolumn{3}{|c|}{ ميانخين مربعات } & \multirow{2}{*}{ درجه آزادى } & \multirow{2}{*}{ منبع تغييرات } \\
\hline دمروباهى سبز & 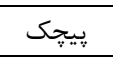 & سلمهتره & & \\
\hline$\cdot / \cdot \nvdash \Lambda * *$ & $r / \Delta$ r** & $.1 .19 * *$ & $r$ & تودههاى بذرى \\
\hline . . . & $\cdot / \cdot V V$ & $\cdot / \cdot$ IV & $\wedge$ & خطا \\
\hline \multirow[t]{3}{*}{$1 \cdot / 41$} & $r / 90$ & V/AF & \multicolumn{2}{|c|}{ درصد ضريب تغييرات } \\
\hline & & & \multicolumn{2}{|c|}{ إ: } \\
\hline & \multicolumn{4}{|c|}{ حدول هـ مقايسه تودههاى بذرى مناطق مختلف براى ميانَّين وزن هزار دانه (بر حسب كرم) } \\
\hline دمروباهى سبز & קוيجكى & & سلمه تره & توده بذرى \\
\hline$\cdot / f r b$ & $1 \cdot 1 \cdot r b$ & &.$/ F T C$ & كشكوئيه \\
\hline.$/ 4 \& b$ & $1 \cdot 1 \cdot r b$ & & $\cdot 19 \cdot \mathrm{a}$ & انار \\
\hline$\cdot|9| \mathrm{a}$ & $11 / \wedge \mathrm{Va}$ & & $\cdot / a \cdot b$ & 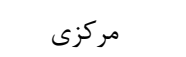 \\
\hline- & $1 \cdot 1 \cdot r b$ & & $\cdot / \Delta \wedge a b$ & نوق \\
\hline $.199 \mathrm{a}$ & - & & - & كبوترخان \\
\hline
\end{tabular}

در هر ستون ميانگينهاى داراى حداقل يك حرف مشترك، بر اساس آزمون دانكن تفاوت معنىدارى در سطح ه. ندارند.

r r • • گرم، كمترين وزن هزار دانه را داشتند (جدول

ه). همجنين نتايج حاصل از مقايسه اثرات اصلى توده هاى مناطق مختلف بر ميانگين درصد جوانهنى نشان داد كه بذرهاى علف هرز سلمهتره توده انار با ميانگين

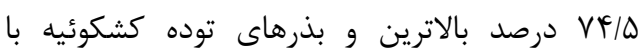

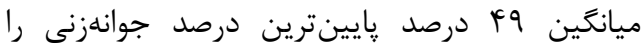
داشتند (شكل () بهطورى كه مىتوان احتمال داد كه دين افزايش وزن هزار دانه در بذرهاى توده انار مى بـونواند علت افزايش درصد جوانهزنى بذرهاى اين توده باشد.

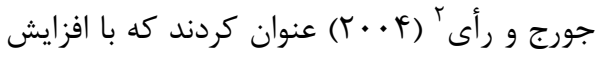
وزن صد دانه كياه بابونه، درصد جوانهزنى افزايش يافت بلهورى كه با افزايش وزن صد دانه از ^ •••

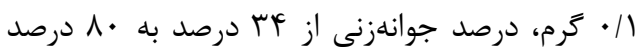

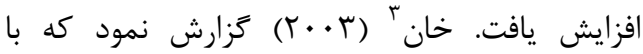
افزايش وزن بذر كياه Artocarpos heterophyllus

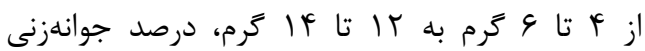

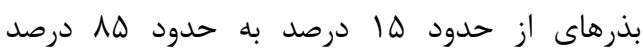
افزايش يافت. - افي

\footnotetext{
${ }^{2}$ Jorge and Ray
}

${ }^{3}$ Khan
شايد غلظتهاى كم، يك مسير ييامرسانى ويزه با دخالت NO و ر راديكالهاى آزاد اكسيرنى را راهاندازى ئى مى كند كه منجر به تحريك جوانهزنى مىشود؛ اما در

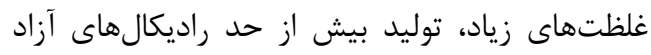

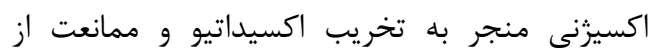
جوانهزنى مىشود. البته درستى اين فرضيه بايد در آينده بررسى شود. بههرحال اين تحقيق نشان داد كه

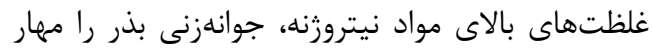

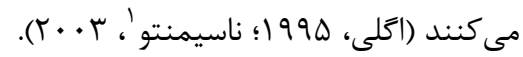
با توجه به اينكه در اين يزوهش تمامى تيمارهاى

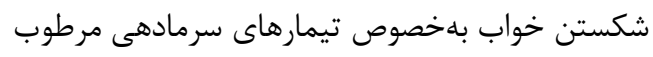
و خراشدهى شيميايى تأثير معنىدارى بر جوانهزنى و

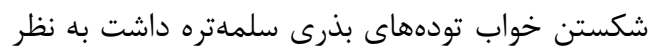

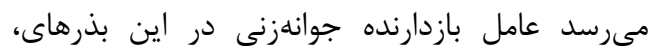

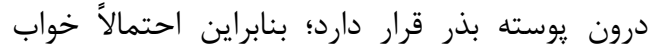
تودههاى بذرى سلمهتره از نوع فيزيولوزيك است.

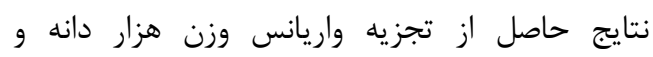
تودههاى بذرى مناطق مختلف براى علف هرز سلمهتره در سطح يك درصد معنى دار گرديد (جدول عأ).

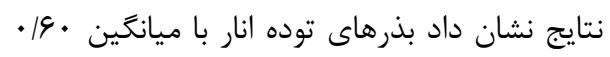
گرم، بالاترين و بذرهاى توده كشكوئيه با ميانگين بان ديان

\footnotetext{
${ }^{1}$ Nascimento
} 
در بعضى از خانوادهها مانند Anacardiaceae خواب فيزيكى بذر به علت فرابر (يريكارب) ناتراواى

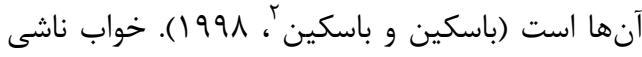

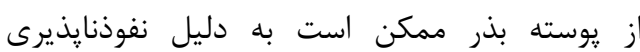

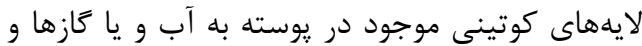

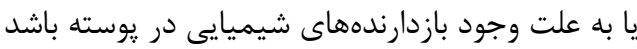

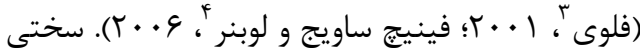

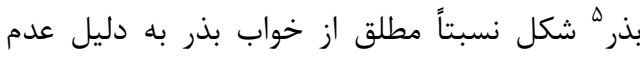

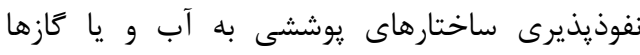

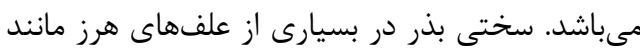

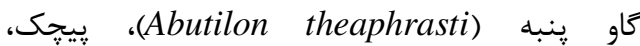
ايارسلام (Cyperus spp) و شيرينبيان (Glycyrrhiza glabra L.)

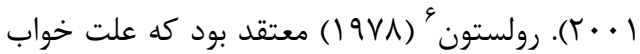

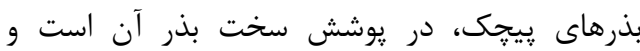
يوشش سخت بذر مانع جوانهزنى است. ايشان

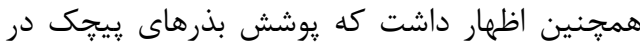

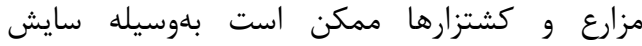

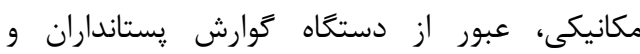
يرندكان، نوسانات درجه حرارت، آتش و و تجزيه

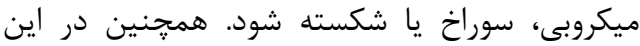

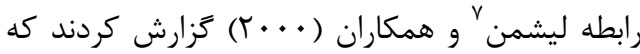
قارجها نقش زيادى در تجزيه ميكروبى يوشش بذرهاى

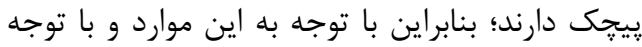

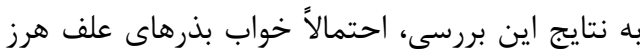

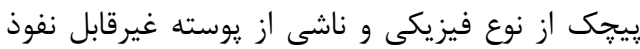

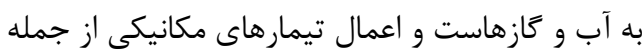

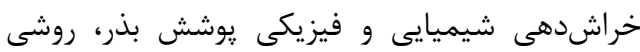

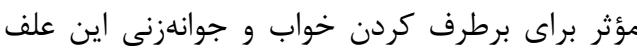

$$
\text { هرز مىباشد. }
$$

با توجه به نتايج جدول V مشخص مىشود كه در تمام تودههاى مورد بررسى با افزايش مدت زمات زمان قرار

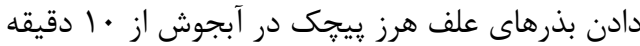

\footnotetext{
${ }^{2}$ Baskin and Baskin

${ }^{3}$ Foley

${ }^{4}$ Finch-Savage and Leubner

${ }^{5}$ Hard seedeness

${ }^{6}$ Rolston

${ }^{7}$ Leishman
}

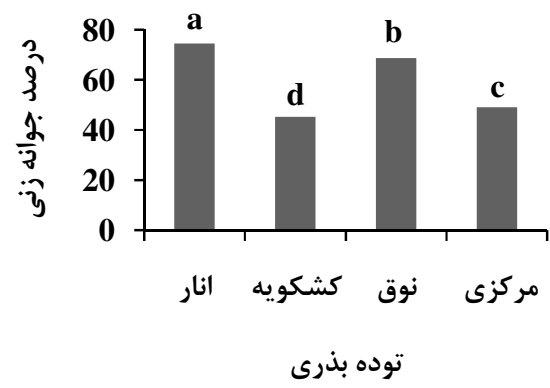

شكل ا- درصد جوانهزنى بذر در تودههاى مختلف سلمهتره

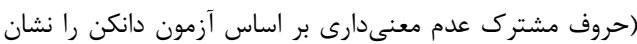
مى مهد). קיيجא نتايج حاصل از تجزيه واريانس نشان داد توده بذرى، تيمارهاى شكستن خواب و برهمكنش توده بذرى و تيمارهاى شكستن خواب اثر معنىدارى بر براب درصد جوانهزنى و متوسط زمان جوانهزنى علف هرز بيجֶى در سطح يك درصد داشتند (جدول 9). نتايج

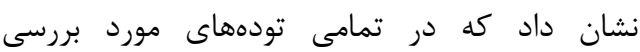
تيمارهاى خراشدهى با سنباده، خيساندن در آبجوش

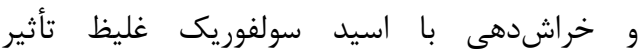
معنىدارى بر درصد جوانهزنى و متوسط زمان جوانهزنى داشتند، بهطورى كه اعمال تيمار خراشدهيى داشي

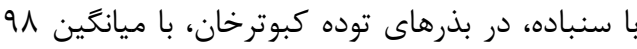
درصد، بالاترين و تيمار شاهد (آب مقطر) در همان توده بذرى، با ميانگين 9 درصد، وايينترين درصد

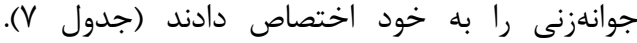

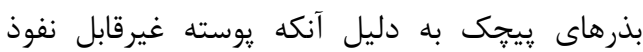

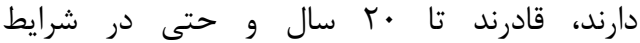

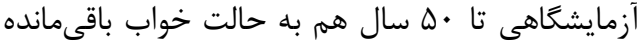

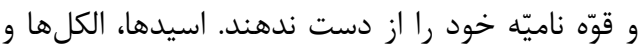
يا خراشهاى مكانيكى از تيمارهاى مؤثر بر شكستكى اين دوره محسوب مىشوند (راشد محصل و همكاران،

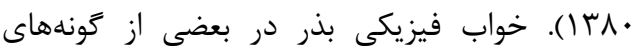

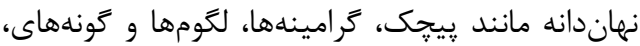
تيره קنيرك بهوسيله يوسته نفوذنايذير بذر به آب، ايجاد مىشود (كاردينا و اسيارو'، ب99 1991).

${ }^{1}$ Cardina and Sparrow 
نتايج حاصل از تجزيه واريانس وزن هزار دانه و تودهاى بذرى مناطق مختلف براى علف هرز يِيجى

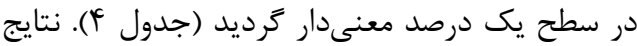

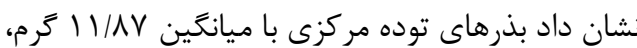
بالاترين وزن هزار دانه را به خود اختصاص داد داد ودان مادي

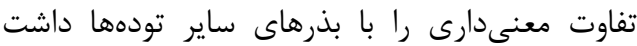

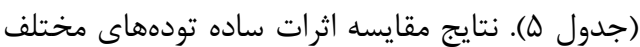
بذرى بر ميانگين درصد جوانهزنى علف هرز زيجِك در اين يزوهش به كونهاى بود كه بذرهاى توده مركزى كه

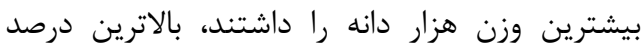
جوانهزنى (1/ / م درصد) را نيز به خود اختصاص دار دادند

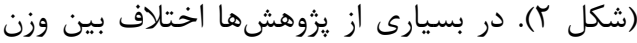

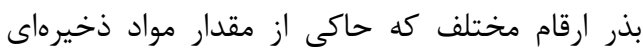

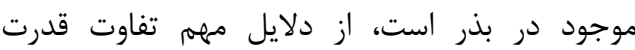

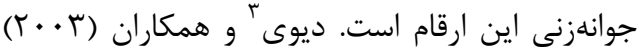
طى آزمايشى بر روى خردل هندى ائدى بيان داشتند كه اندازه بذر بر بنيه بذر تأثيركذار است و بذرهاى داري دارئ داى دائ وزن بيشتر، قوه ناميه بالاترى داشته و در آزمون هدايت الكتريكى تراوش كمترى داشتند.

\section{علف هرز دمروباهى سبز}

نتايج حاصل از تجزيه واريانس نشان داد توده بذرى، تيمارهاى شكستن خواب و برهمكنش توده بذرى و تيمارهاى شكستن خواب اثر معنىدارى بر درصد جوانهزنى و متوسط زمان جوانهزنى علف هرز دمروباهى سبز در سطح احتمال يك درصد داشتند

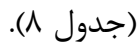

نتايج نشان داد كه در تمام تودههاى مورد بررسى دئ تيمارهاى اسيد جيبرليك بالاترين درصد جوانهزنى را تران

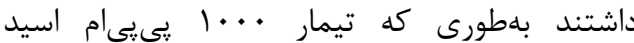
جيبرليك در توده كبوترخان با ميانگين •و درصد
به ها دقيقه، درصد جوانهزنى افزايش و متوسط زمان جوانهزنى كاهش يافت بلهطورى كه در تمامى تودهها، اعمال تيمار ها دقيقه قرار دادن بذرهاى علف هرز

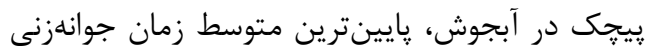
را به خود اختصاص داد و تفاوت معنى دارى را با باين ساير تيمارها داشت (جدول V). افزايش در ميزان و سرعت إدان

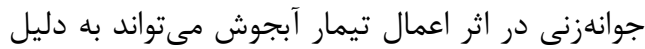
كاهش ضخامت يوسته بذر و افزايش جذب آب و آماس بذر، رهايى از محدوديت فيزيكى يوشش بذر واهن واند

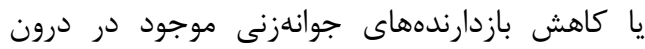
جنين باشد (ابراهيمى و اسلامى، آوبا). نتايج تيمار آبجوش در زمانهاى مختلف مؤيد اين نكته است كه آنها

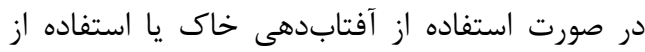
شعله افكن يا آتش زدن بقايا در مديريت بانك بذر اين إنا

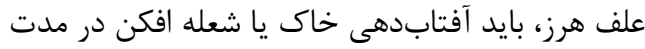
زمان طولانى و با دماى مناسب صورت گيرد، در غير بإنا اين صورت به دليل يوسته ضخيم بذر بى تأثير و حتى ممكن است باعث برطرف شدن خواب بذر نيز گرددد.

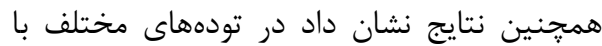
افزايش مدت زمان تيمار با اسيد سولفوريك غليظ از

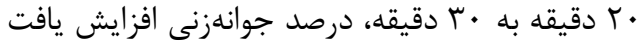
كه اين افزايش جوانهزنى در بذرهاى علف هرز يِيجى دئه

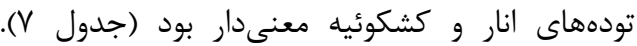

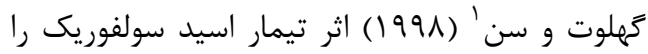
روى بذرهاى علف مورجه (Cressa cretica) مورد مطالعه قرار داد و نتيجه كرفت كه تيمار اسيد سولفوريك باعث افزايش جوانهزنى بذر علف مورجه كرديد و با افزايش زمان قرار دادن بذرهاى دائ در اسيد از صفر تا ها دقيقه، درصد جوانهزنى افزايش يافت بران.

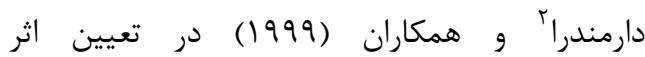
و اسيد سولفوريك بر جوانهزنى كونه لوبياى درختى دارنى نتيجه كرفت كه خراشدهى (Sebania rostrata) مكانيكى و شيميايى (اسيد سولفوريك) باعث افزايش درصد و سرعت جوانهزنى شده و تيمار اسيد سولفوريك غليظ جوانهزنى را تا س/و9 درصد افزايش

${ }^{1}$ Gehlot and Sen

${ }^{2}$ Dharmendra

${ }^{3}$ Devi 
جدول و- تجزيه واريانس تأثير توده بذرى و تيمارهاى شكستن خواب بذر بر درصد و متوسط زمان

جوانهزنى علف هرز يِيجى

\begin{tabular}{|c|c|c|c|}
\hline \multicolumn{2}{|c|}{ ميانگين مربعات } & \multirow{2}{*}{ آزادى } & \multirow{2}{*}{ منبع تغييرات } \\
\hline متوسط زمان جوانهزنى & درصد جوانهزنى & & \\
\hline $1 / 9 r^{*}$ & $r r V / 9 r^{* * *}$ & $r$ & توده بذرى \\
\hline$r G r / V I^{* *}$ & $1 \cdot \Lambda \Lambda \cdot / v \cdot^{* *}$ & $\Delta$ & تيمارهاى شكستن خواب \\
\hline $9 / 91^{* *}$ & $r \Delta r / A V^{* *}$ & 10 & توده بذرى×تيمارهاى شكستن خواب \\
\hline ( & He/TV & VT & خطا \\
\hline $1 V / 99$ & $V / V \Delta$ & - & ضريب تغييرات (درصد) \\
\hline
\end{tabular}

جدول V- مقايسه اثرات متقابل توده بذرى و تيمارهاى شكستن خواب بذر براى ميانگين درصد و زمان جوانهزنى بذرهاى بيجِك

\begin{tabular}{|c|c|c|c|}
\hline \multirow{2}{*}{ متوسط زمان جوانهزنى (روز) } & \multirow{2}{*}{ درصد جوانهزنى } & \multicolumn{2}{|l|}{ تيمار ها } \\
\hline & & روشهاى شكستن خواب بذر & توده بذرى \\
\hline$r / \cdot 1 d-g$ & $9 \mathrm{Vf}$ & اسيد سولفوريك ·r دقيقه & \\
\hline$r / 4 \notin \mathrm{d}-\mathrm{h}$ & $\Lambda \cdot e$ & اسيد سولفوريك •r دقيقه & \\
\hline$r / \cdot \wedge e-h$ & qra-d & خراشدهى با سمباده & \\
\hline$r / 4 r d-h$ & ^৭a-e & آبجوش · ا دقيقه & أنار \\
\hline l/Argh & qra-d & آبجوش ها دقيقه & \\
\hline $19 / V 1 a$ & rih & شاهد (آب مقطر) & \\
\hline r/৭९d-g & $99 f$ & اسيد سولفوريك · · دقيقه & \\
\hline$r / 19 e-h$ & ^rde & اسيد سولفوريك • ب دقيقه & \\
\hline l/Avefg & qra-d & خراشدهى با سمباده & \\
\hline $1 / \Delta \Delta \mathrm{h}$ & qra-d & آبجوش • ا دقيقه & لسلوتيه \\
\hline $1 / \& \Delta h$ & $9 \Delta \mathrm{abc}$ & آبجوش ها دقيقه & \\
\hline $19 / \pi \mathrm{ra}$ & rigg & شاهد (آب مقطر) & \\
\hline$r / 9 \Delta d$ & $\wedge \Leftrightarrow \mathrm{b}-\mathrm{e}$ & اسيد سولفوريك · · دقيقه & \\
\hline$r / r \mid d e f$ & ara-d & سولفوريك ·ـ دقيقه اسيد & \\
\hline r/frd-h & $१ ९ \mathrm{ab}$ & خراشدهى با سمباده & \\
\hline$\Gamma / \Gamma \cdot \mathrm{de}$ & $\wedge \Delta \mathrm{cde}$ & آبجوش • ا دقيقه & مر رزى \\
\hline 1/9 refg & 91a-d & آبجوش ها دقيقه & \\
\hline$|r / r| b$ & rqg & شاهد (آب مقطر) & \\
\hline$r / \Delta V d$ & $91 a-d$ & اسيد سولفوريك · · دقيقه & \\
\hline r/qrd-h & ^९а-e & اسيد سولفوريك • ب دقيقه & \\
\hline $1 / 9 \wedge \mathrm{e}-\mathrm{h}$ & $9 \wedge \mathrm{a}$ & خراشدهى با سمباده & \\
\hline r/q)d-h & $\wedge \Delta c d e$ & آبجوش • ا دقيقه & دبور حان \\
\hline 1/9 $\mathrm{fgh}$ & 91a-d & آبجوش ها دقيقه & \\
\hline $11 / \cdot 1 \mathrm{c}$ & $9 \mathrm{i}$ & شاهد (آب مقطر) & \\
\hline
\end{tabular}


همكاران (r (I ا) نيز كزارش كردند كه از بين تيمارهاى مختلف هورمونى و سرمادهى اعمالشده، تيمار اسيد جيبرليك بهترين تيمار براى شكستن

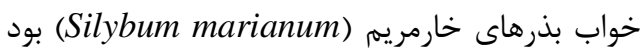
بهطورى كه در بررسى آنها بيشترين درصد و سرعت

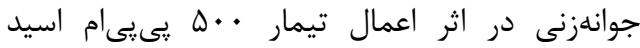

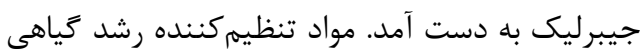
در ايجاد و كنترل خواب فيزيولوزيكى بذر، نقش

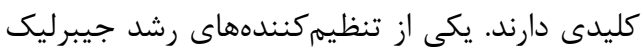
اسيد مىباشد كه از طريق القاء جوانهزنى در در شكستن خواب بذر تأثير مى كذارد (باسكين و باسكين،

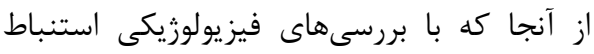

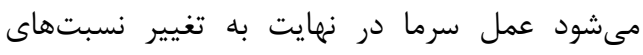
هورمونى درونى بذر به نفع جيبرلين منجر خواهد شد دان

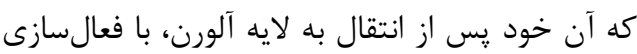

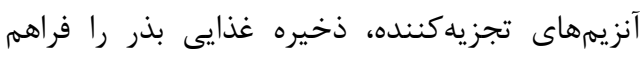
مىكنند، متخصصان بذر معتقدند كه اين هورمون مىتواند جانشين مناسبى براى برطرف كردن بدان نياز

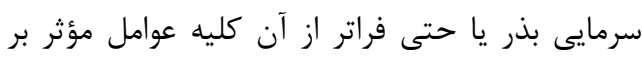

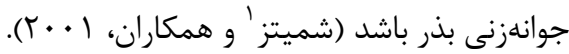

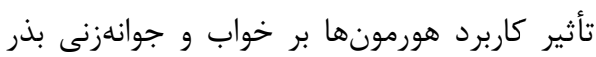

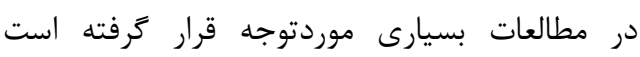

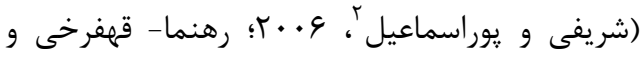

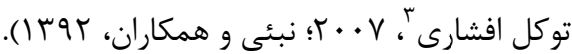

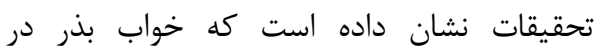
كراسها، خواب فيزيولوزيكى سطحى است (باسكين و دات دان باسكين، 1991) (199). لذا با توجه به اينكه اسيد جيبرليك، جزو مواد تحريككننده رشد محسوب مى كردد، مىتوان نتيجه

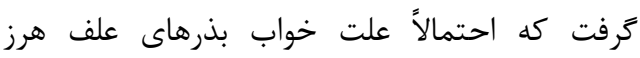

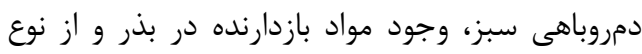

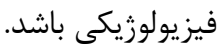

\footnotetext{
${ }^{1}$ Schmitz

${ }^{2}$ Sharifi and Pouresmaeil

${ }^{3}$ Rahnama-Ghahfarokhi and Tavakkol-Afshari
}

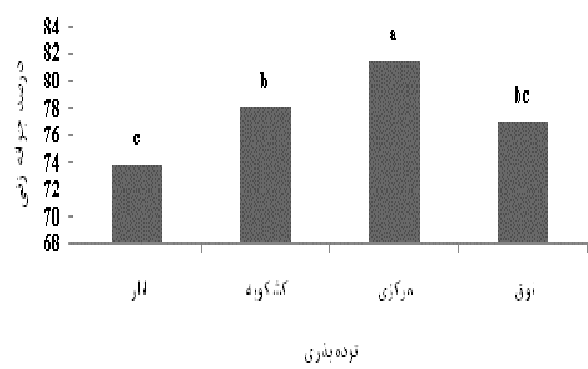

شكل r- درصد جوانهزنى بذر در تودههاى مختلف يِيجى (حروف مشترك عدم معنى دارى بر اساس آزمون دانكن را نشان

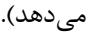
جدول 1- تجزيه واريانس تأثير توده بذرى و تيمارهاى شكستن خواب بذر بر درصد و متوسط زمان جوانهزنى علف هرز دم روباهى سبز

\begin{tabular}{|c|c|c|c|}
\hline \multicolumn{2}{|c|}{ ميانگين مربعات } & \multirow[b]{2}{*}{ آزادى درجه } & \multirow[b]{2}{*}{ منبع تغييرات } \\
\hline متوسط زمان & درصد جوانهزنى & & \\
\hline$V / \Gamma 1^{* *}$ & ITrY/AD*** & $r$ & توده بذرى \\
\hline$q 4 / \cdot \Lambda^{* *}$ & rVAr/r & $\wedge$ & شكستن خواب \\
\hline$\Delta / r \Delta^{* *}$ & $1 \Delta 9 / V \varphi^{* *}$ & TF & توده بذرى × تيمارهاى \\
\hline$\cdot / 11$ & $|V / \Lambda|$ & $1 \cdot 1$ & خطا \\
\hline$\Lambda / \Gamma \Delta$ & $r \cdot / 1 T$ & رصد) & ضريب تغييرات \\
\hline
\end{tabular}

بالاترين و تيمار شاهد (آب مقطر) در تودههاى انار و

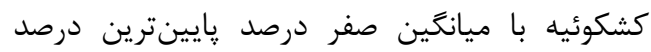
جوانهزنى را داشتند (جدول 9)

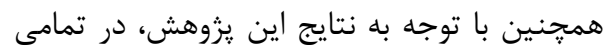

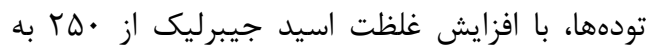

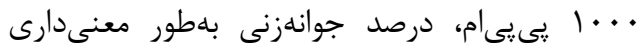

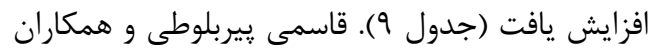

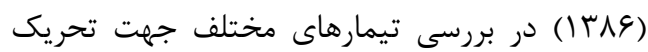
جوانهزنى ه گياه دارويى مشاهده نمودند كه تيمار

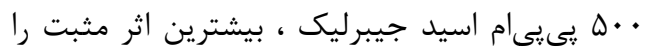
بر جوانهزنى كونهاى آويشن دنايى (Hyssopus officinalis) روفان daenesis) بومادران (Achillea millefolium) و و باديان بواشته است. نبئى و و (Pimpinella anisum) 
$\Lambda r$

مجله : مُوهش هاى بذر ايران / سال سوم/ شماره دوم/ هوسا

جدول 9- مقايسه اثرات متقابل توده بذرى و تيمارهاى مختلف شكستن خواب براى ميانكَين درصد جوانهزنى و زمان جوانهزنى بذرهاى

دمروباهى سبز

\begin{tabular}{|c|c|c|c|}
\hline \multirow{2}{*}{ متوسط زمان جوانهزنى (روز) } & \multirow{2}{*}{ درصد جوانهزنى } & \multicolumn{2}{|l|}{ تيمار ها } \\
\hline & & روشهاى شكستن خواب بذر & توده بذرى \\
\hline $9 / \pi \backslash a$ & $\Delta$ no & نيترات يتاسيم ppm 500 & \\
\hline$\Lambda / 9 b c d$ & smno & pيترات يتاسيم ppm 1000 & \\
\hline V/Vrcd & $11 \mathrm{mvl}$ & ppm اسيد جيبرليك 250 & \\
\hline$\varepsilon / \mathcal{k} \cdot \mathrm{ef}$ & $r \Delta f-i$ & ppm 500 اسيد جيبرليك & \\
\hline$\Delta / r \wedge h i$ & rqc & ppm اسيد جيبرليك 1000 & 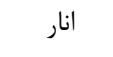 \\
\hline r/qrij & rlhij & سرمادهى مرطوب يك هفته & \\
\hline$r / \wedge \wedge \mathrm{m}$ & 9mnl & سرمادهى مرطوب سه هفته & \\
\hline $\mathrm{f} / \mathrm{r} \cdot \mathrm{kl}$ & iهjkl & سرمادهى مرطوب ينج هفته & \\
\hline$\cdot \mathrm{p}$ & $\cdot 0$ & شاهد (آب مقطر) & \\
\hline$V / 49 d$ & ro & نيترات يتاسيم ppm 500 & \\
\hline$\Lambda / r \cdot b c$ & \&mno & ppm نيترات يتاسيم ppo0 & \\
\hline V/DFd & $11 \mathrm{mnl}$ & اسيد جيبرليك 250 ppm & \\
\hline g/Are & $r \varphi f-i$ & ppm 500 اسيد جيبرليك & \\
\hline$\Lambda / \Delta 9 b$ & $\Delta \cdot b$ & ppm اسيد جيبرليك 1000 & كشكويه \\
\hline 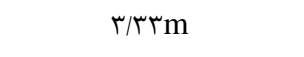 & r^efg & سرمادهى مرطوب يك هفته & \\
\hline$r / f \backslash m$ & $1 r \mathrm{ml}$ & سرمادهى مرطوب سه هفته & \\
\hline $\mathrm{r} / \wedge \wedge \mathrm{kl}$ & r^efg & سرمادهى مرطوب ينج هفته & \\
\hline$\cdot \mathrm{p}$ & $\cdot 0$ & شاهد (آب مقطر) & \\
\hline$s / 4 i e f$ & $1 \mathrm{fkl}$ & 500 ppm نيترات يتاسيم & \\
\hline ه/Vrgh & røf-i & 1000 ppm نيترات يتاسيم & \\
\hline$\Delta / v \wedge f g h$ & $\mid \mathrm{fkl}$ & 250 ppm اسيد جيبرليك & \\
\hline$\Delta / \Delta \Delta \mathrm{ghi}$ & rqefg & 500 ppm اسيد جيبرليك & \\
\hline F/qrij & $\Delta \Delta \mathrm{ab}$ & 1000 ppm اسيد جيبرليك & 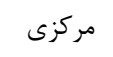 \\
\hline$r / r \wedge \mathrm{m}$ & | $\mathrm{kkl}$ & سرمادهى مرطوب يك هفته & \\
\hline ץ/q६ij & rrghi & سرمادهى مرطوب سه هفته & \\
\hline$F / Q \digamma j \mathrm{jkl}$ & $r \cdot \mathrm{ijk}$ & سرمادهى مرطوب ينج هفته & \\
\hline I/FYo & 9mnl & شاهد (آب مقطر) & \\
\hline$\Delta / r \Delta h i$ & $r \Delta f-i$ & 500 ppm نيترات يتاسيم & \\
\hline$\Delta / \wedge \wedge f g h$ & Tre-h & 1000 ppm نيترات پيتاسيم & \\
\hline s/rrefg & $r \cdot$ edf & 250 ppm اسيد جيبرليك & \\
\hline ه/rıhi & racd & 500 ppm اسيد جيبرليك & \\
\hline $\mathrm{f} / \mathrm{QVj \textrm {j }}$ & $9 \cdot \mathrm{a}$ & 1000 ppm اسيد جيبرليك & كبوترخان \\
\hline$\Gamma / \Delta / \mathrm{m}$ & rrdef & سرمادهى مرطوب يك هفته & \\
\hline ऍ/qrklm & rve-h & سرمادهى مرطوب سه هفته & \\
\hline D/DVghi & $1 r \mathrm{ml}$ & سرمادهى مرطوب ينج هفته & \\
\hline$r / f \Delta \mathrm{n}$ & 9mnl & شاهد (آب مقطر) & \\
\hline
\end{tabular}


بيانكَر تأثير معنىدار شرايط آب و هوايى، جغرافيايى و

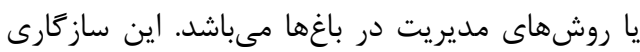

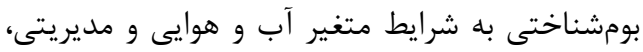
موجب مىشود اين علفهاى هرز در تمام مناطق بنق

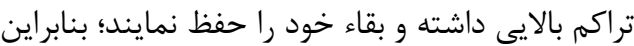

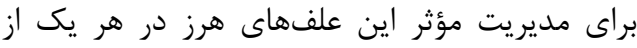

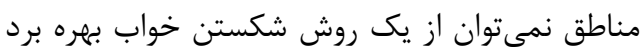

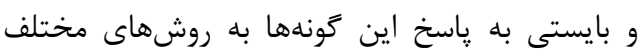

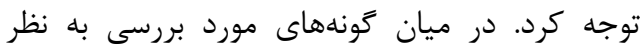

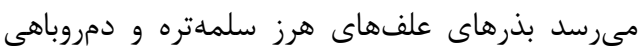

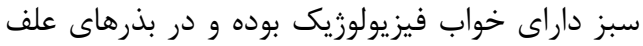
هرز پيجیى به دليل نقش مؤثر يوسته بذر، خواب

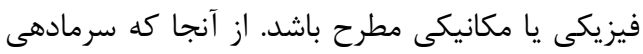
مرطوب در بذرهاى سلمهتره، خراشدهى در بذرهاى

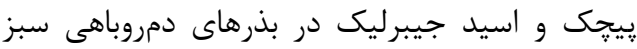

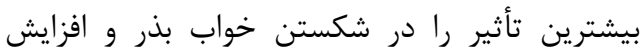
جوانهزنى داشت و همجنين با توجه به تأثير متفاوت هر يك از روشها در مناطق مختلف، براى مديريت

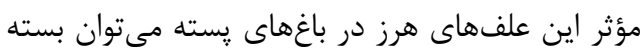

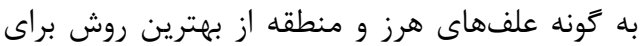
تحريك جوانهزنى و يا كاهش جوانهزنى بذرهاى در بانك بذر بهره برد.

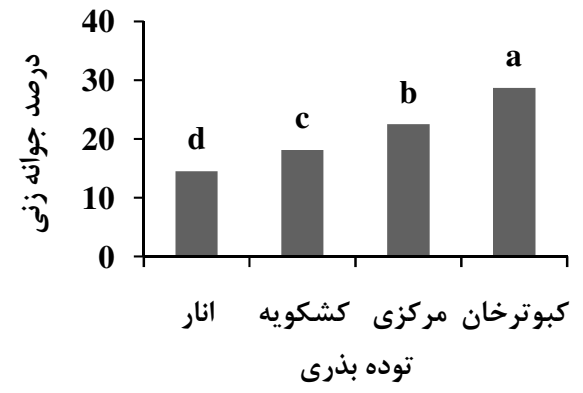

شكل ץ- درصد جوانهزنى بذر در تودهاى مختلف دمروباهى

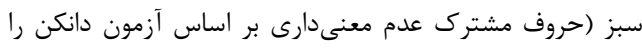

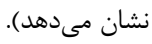

نتايج حاصل از تجزيه واريانس وزن هزار دانه و تودههاى بذرى مناطق مختلف براى علف هرز دمروباهى سبز در سطح يك درصد معنىدار كرديد (جدول \&). نتايج نشان داد بذرهاى توده كبوترخان

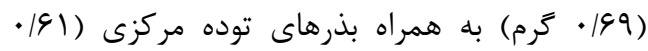

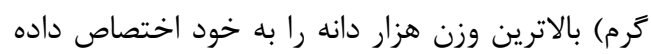
و تفاوت معنىدارى را با بذرهاى تودههاى انار و و دارئ

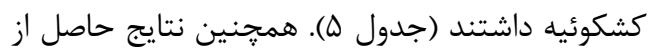

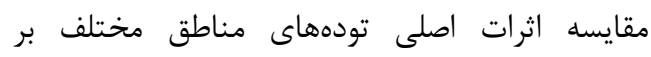
ميانكين درصد جوانهزنى نيز نشان داد كه بذرهاى علف هرز دمروباهى سبز توده كبوترخان بالاترين و وردان

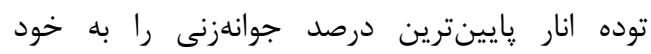

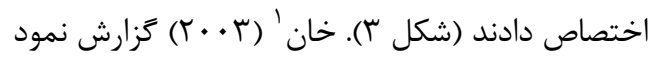
كه همبستكى مثبت و معنى دارى بين وزن بذر و و

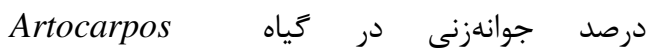
heterophyllus L. وجود ارتباط بين ويزگى هاى ظاهرى و فيزيكى بذر با نحوه سبز شدن و رشد خياهجه توسط ساير

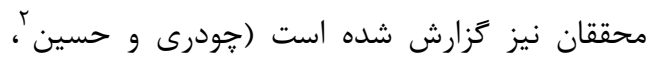

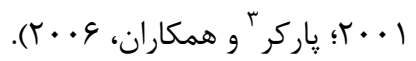

\section{نتيجه كيرى}

نتايج اين تحقيق نشان مىدهد كه در هر كونه

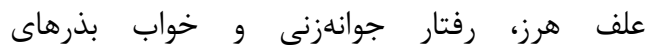
جمعآورىشده از مناطق مختلف متفاوت بوده كه

\footnotetext{
${ }^{1}$ Khan

${ }^{2}$ Chaudhry and Hussain

${ }^{3}$ Parker
} 
ابراهيمى، ا. و اسلامى، و. ا9 91 ا. تأثير تيمارهاى مختلف در شكستن خواب و جوانهزنى بذرهاى سس شرقى (عuscuta (monogyna Vahi

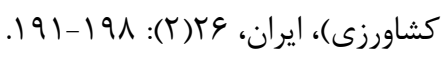

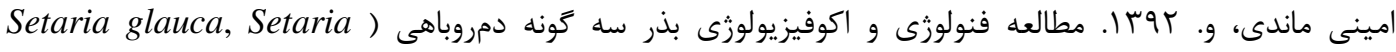
(verticillata, Setaria viridis

$$
\begin{aligned}
& \text { طبيعى سارى. • • (1 صفحه. }
\end{aligned}
$$

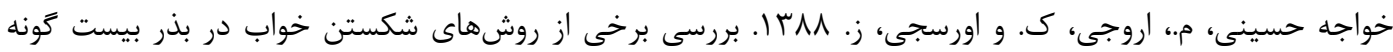

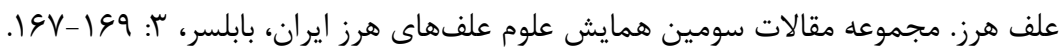

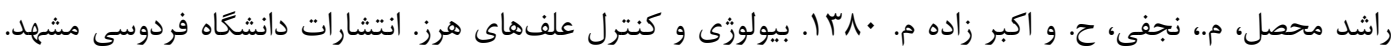

$$
\begin{aligned}
& \text {. }
\end{aligned}
$$

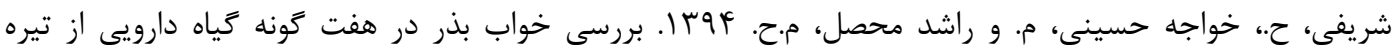

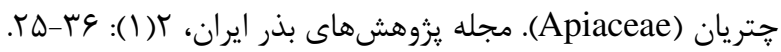

$$
\begin{aligned}
& \text { قاسمى پِيربلوطى، ع.، كليرور، ا.، رياحى دهكردى، م. و نويد، ع. عاب ا. بررسى اثر تيمارهاى مختلف در شكستن خواب }
\end{aligned}
$$

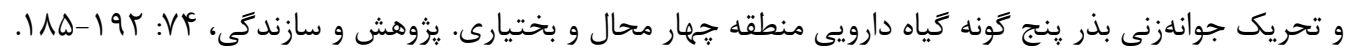

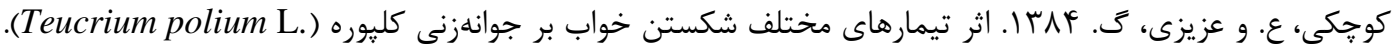

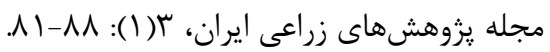

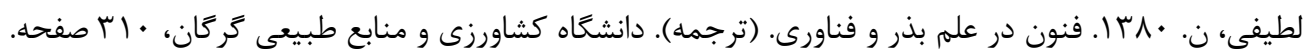

$$
\begin{aligned}
& \text { محمدى، ق.، جلالى هنرمند، س.، محمدخواه، ا. و احمدى، غ. •وسا. جوانهزنى بذر. انتشارات آموزش و ترويج }
\end{aligned}
$$

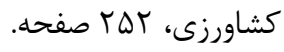

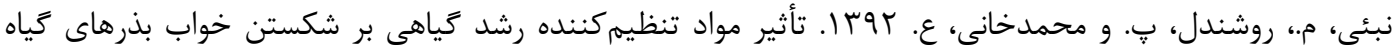

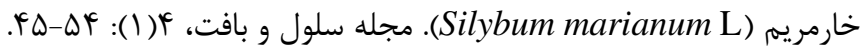

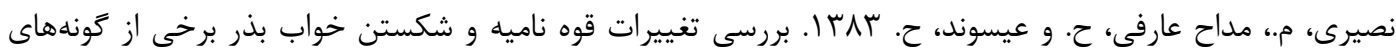

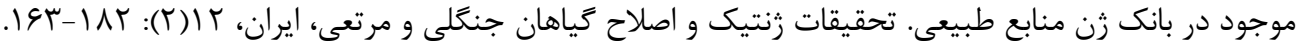

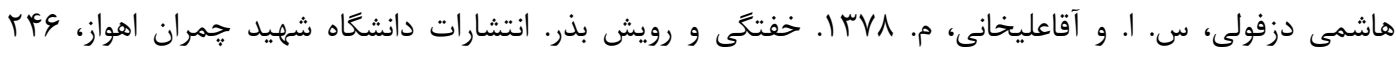

$$
\begin{aligned}
& \text { صفحه. }
\end{aligned}
$$

Anonymous, 2013. http:/deal.unl.edu/cornpro/html/weed /wbiology.html.

Baskin, C.C., and Baskin, J.M. 1998. Seeds: Ecology, biogeography, and evolution of dormancy and germination. Academic Press, San Diego, 666 p.

Batlla, D., Kruk, B.C., and Benech-Arnold, R.L. 2004. Modelling changes in dormancy in weed soil seed banks: implications for the prediction of weed emergence. Handbook of seed physiology. Applications to agriculture. New York: Haworth Press Inc, 245-264.

Cardina, J., and Sparrow, D.H. 1997. Temporal changes in velvetleaf (Abutilon theophrasti) seed dormancy. Weed Science, 45(1): 61-66. 
Chaudhry, A.U., and Hussain, I. 2001. Influence of seed size and seed rate on phenology, yield and quality of wheat. Pakistan Journal of Biological Sciences, 4(4): 414-416.

Copeland, L.O., and McDonald, M.B. 2001. Principles of seed science and technology. dordrecht, The Netherlands: Kluwer Academic Publishers, 475p.

Devi, L., Chitra-Kant, K., and Dadlani, M. 2003. Effect of size grading and ageing on sinapine leakage, electrical conductivity and germination percentage in the seed of mustard (Brassica juncea L.). Seed Science and Technology, 31(2): 505-509.

Dharmendra, K., Pyare, L., and Kumar, D. 1999. Improving germination of Sesbania rostrata green manure crop. Seed Research, 27(1): 20-24.

Egley, G.H. 1995. Seed germination in soil: dormancy cycles. Seed development and germination. New York: Marcel Dekker, 529-543.

Finch-Savage, W.E., and Leubner-Metzger, G. 2006. Seed dormancy and the control of germination. Tansley Review- New Phytologist, 171(3): 501-523.

Foley, M.E. 2001. Review article: seed dormancy: an update on terminology, physiological, genetics, and quantitative trait loci regulating germinability. Weed Science, 49(3): 305-317.

Garcia-Gusano, M., Martinez-Gomez, P., and Dicenta, F. 2004. Breaking seed dormancy in almond (Prunus dulcis (Mill.) D.A. Webb). Scientia Horticulturae, 99(3): 363-370.

Gehlot, A.K., and Sen, D.N. 1998. Effect of acid scarification on percent germination, vigor index and germination rate in Cressa cretica (Linn.). Journal of Eco-Physiology, 1(3/4): 7982.

International Seed Testing Association. 1996. International rules for seed testing. Seed Science and Technology, 13: 299-513.

Irvani, N., Solouki, M., Omidi, M., Saidi, A., and Zare, A. 2012. Seed germination and dormancy breaking in Orema ammoniacum D. an endangered medicinal plant. Trakia Journal of Sciences, 10(1): 9-15.

Jorge, M.H.A., and Ray, D.T. 2004. Germination characterization of Guayule (Parthenium argentatum) seed by morphology mass and X-ray and analysis. Industrial Crops and Products, 22(1): 59-63.

Karam, N.S., and Al-salem, M.M. 2001. Breaking dormancy in Arbutus andrachne L. seeds by stratification and gibberelic acid. Seed Science and Technology, 29(1): 51-56.

Karssen, C.M., and Hillhourst, H.W.M. 1992. Chemical environment of seed germination. In: M. Fenner (ed). Seeds: The ecology of regeneration in plant communities. Wallingford: CAB International, 327-348.

Khajeh-Hossini, M., Lomhololt, A., and Matthews, S. 2009. Mean germination in the laboratory estimates the relative vigour and fild performance of commertial seeds lots of maize (Zea mays L.). Seed Science and Technology, 37(2): 446- 456.

Khan, M.L. 2003. Effects of seed mass on seedling success in Artocarpus heterophyllus L. a tropical tree species of north - east India. Acta Oecologia, 25(1): 103-110.

Koornneff, M., Bentsink, L., and Hilhorst, H. 2002. Seed dormancy and germination. Current Opinion in Plant Biology, 5(1): 33-36.

Leishman, M.R., Masters, G.J., Clarke, I.P., and Brown, V.K. 2000. Seed bank dynamics: the role of fungal pathogens and climate change. Functional Ecology, 14(3): 293-299.

Nascimento, W.M. 2003. Muskmelon seed germination and seedling development in response to seed priming. Sciatica Agricola, 60(1): 71- 75. 
Parker, W.C., Noland, T.L., and Morneault, A.E. 2006. The effects of seed mass on germination, seedling emergence, and early seedling growth of eastern white pine (Pinus strobus L.), New Forests, 32(1): 33-49.

Radosevich, S.R., Holt, J.S., and Ghersa, C.M. 2007. Ecology of weeds and invasive plants: relationship to agriculture and natural resource management. John Wiley \& Sons, Inc., Hoboken, NJ, USA.

Rahnama-Ghahfarokhi, A., and Tavakkol-Afshari, R. 2007. Methods for dormancy breaking and germination of galbanum seeds (Ferula gummosa). Asian Journal of Plant Science, 6(4): $611-616$.

Rolston, M.P. 1978. Water impermeable seed dormancy. Botanical Review, 44(3): 365-396.

Rouhi, H.R., Rahmati, H., Saman, M., Shahbodaghloo, A.R., Karimi, F.A., Moosavi, S.A., Rezaei, M.E., and Arimi, F. 2012. The effects of different treatments on dormancy-breaking of Galbanum seeds (Ferula gummosa Boiss.). International Journal of Agriculture Science, 2(7): 598-604.

Schmitz, N., Xia, J.H., and Kermode, A.R. 2001. Dormancy of yellow cedar seeds is terminated by gibberellic acid in combination with fluridone or with osmotic priming and moist chilling. Seed Science and Technology, 29(2): 331-346.

Serrano, C., Chueca, M.C., and Garica-Baudin, J.M. 1992. A study of germination in Bromos spp. In: proceeding ofthe 1992 congress of Spanish weed science society. Madrid spaniociedal spanola de Malberbolgia. pp: 217- 221.

Sharifi, M., and Pouresmael, Z.M. 2006. Breaking seed dormancy in Bunium persicum by stratification and chemical substances. Asian Journal of Plant Sciences, 5(4): 695-699.

Tang D.S., Hamayun, M., Ko, Y.M., Zhang, Y.P., Kang, S.M., and Lee, I.J. 2008. Role of red light, temperature, stratification and nitrogen in breaking seed dormancy of Chenopodium album L. Journal of Crop Science and Biotechnology, 11: 199 - 204.

Thurk, M. 1998. Old man saltbush seed treatment for germination improvement. AgriculturalTropical- et. Subtropical, 31:53-59.

Vandelook, F., Bolle, N., and Van- Assche, J.A. 2007. Seed dormancy and germination of the European Chaerophyllum temulum (Apiaceae), a member of a Trans-Atlantic genus. Annals of Botany, 100(2): 233-239. 


\title{
The Study of Seed Germination and Dormancy of Chenopodium album, Convolvulus arvensis and Setaria viridis in Pistachio Orchards of Rafsanjan, Iran
}

\author{
Mostafa Alinaghizadeh ${ }^{1, *}$, Mohammad Khajeh-Hosseini' ${ }^{2}$, Seyed Ahmad Hosseini ${ }^{3}$, \\ Mohammad Hasan Rashed Mohasel ${ }^{4}$ \\ ${ }^{1}$ Assistant Professor of Department of Agricultural, Payame Noor University (PNU), Iran \\ ${ }^{2,4}$ Assistant Professor of Department of Crop Science, Ferdowsi University of Mashhad, Iran \\ ${ }^{3}$ Assistant Professor of Department of Agronomy Science, Vali-e-Asr University of Rafsanjan, \\ Iran \\ *Corresponding author, E-mail address: alinaghizadeh@pnu.ac.ir
}

(Received: 19.04.2016 ; Accepted: 31.10.2016)

\begin{abstract}
In order to study the seed germination behavior and dormancy breaking methods of three weed species (i.e., Chenopodium album, Convolvulus arvensis and Setariaviridis) of pistachio orchards in Rafsanjan, Iran, three separate factorial experiments (with 2 factors) were conducted based on a completely randomized design with four replications, at the Faculty of Agriculture, Vali-E-Asr University of Rafsanjan, Iran, in 2014. Weed seeds were collected from five different regions of Rafsanjan, such as Markazi, Anar, Koshkoiyeh, Kabotarkhan and Nogh. Dormancy breaking treatments for Chenopodium album involved distilled water (control), $\mathrm{KNO}_{3}$ (at 500 and $1000 \mathrm{ppm}$ ), chemical scarification by sulfuric acid (for 5 and $10 \mathrm{~min}$ ), and cold stratification (for 1, 3 and 5 weeks). Treatments for Convolvulus arvensis involved distilled water (control), scarification by sandpaper, chemical scarification by sulfuric acid (20 and 30 $\mathrm{min}$ ), and boiling water (for 15 and $30 \mathrm{~min}$ ). Treatments for Setaria viridis involved distilled water (control), gibbereilic acid (250, 500 and $1000 \mathrm{ppm}), \mathrm{KNO}_{3}(500$ and $1000 \mathrm{ppm}$ ), and cold stratification (for 1, 3 and 5 weeks). The results showed that seed germination percentage (SGP) and mean germination time (MGT) of three weed species were significantly different among weed populations and dormancy breaking methods. For Chenopodium album, cold stratification of 5 weeks resulted in highest SGP (97\%) in Nogh population. For Convolvulus arvensis and Setaria viridis, the highest SGP was obtained after scarification by sandpaper $(98 \%$ in Kabotarkhan population), and using 1000 ppm gibbereilic acid (60\% in Kabotarkhan population), respectively. In addition, increasing the weight of 1000 seeds in the three weed species in question increased SGP.
\end{abstract}

Keywords: Cold Stratification, Gibbereilic Acid, $\mathrm{KNO}_{3}$, Scarification, Seed Dormancy 